\title{
Synthesis and Characterization of Zinc Oxide Nanoparticles with Small Particle Size Distribution
}

\author{
Nuraqeelah Mohammad Shamhari, ${ }^{1}$ Boon Siong Wee, ${ }^{1,}$ \\ Suk Fun Chin ${ }^{1}$ and Kuan Ying Kok ${ }^{2}$ \\ ${ }^{1}$ Faculty of Resource Science and Technology, Universiti Malaysia Sarawak, Kota Samarahan, 94300 Sarawak, Malaysia. \\ ${ }^{2}$ Malaysian Nuclear Agency, Bangi, Kajang, 43000 Selangor, Malaysia. \\ *Corresponding author: E-mail: swboon@unimas.my \\ Tel: +6082582965
}

Received: 24-01-2018

\begin{abstract}
Solvothermal synthesis has shown to have a great potential to synthesize Zinc Oxide nanoparticles (ZnO NPs) with less than $10 \mathrm{~nm}$ size. In this study, we present a rapid synthesis of $\mathrm{ZnO} N P s$ in which ZnO NPs with more uniform shape and highly dispersed were synthesized using zinc acetate dihydrate $\left(\mathrm{Zn}\left(\mathrm{CH}_{3} \mathrm{COO}\right)_{2} 2 \mathrm{H}_{2} \mathrm{O}\right)$ and potassium hydroxide $(\mathrm{KOH})$ as a precursor and absolute ethanol as solvent via solvothermal method. Few techniques were exploited to characterize synthesized ZnO NPs including X-ray diffraction (XRD), transmission electron microscope (TEM), Brunauer-Emmett-Teller (BET), energy-dispersive X-ray spectroscopy (EDX), fourier transform infrared (FT-IR) spectroscopy, and ultraviolet visible (UV-Vis) spectroscopy. Synthesized ZnO NPs that were prepared via solvothermal synthesis method at $60^{\circ} \mathrm{C}$ for 3 hours exhibited a wurtzite structure with a crystalline size of $10.08 \mathrm{~nm}$ and particle size of $7.4 \pm 1.2 \mathrm{~nm}$. The $\mathrm{UV}$-vis absorption spectrum has shown peak at $357 \mathrm{~nm}$ indicate the presence of $\mathrm{ZnO}$ NPs. Hence, better quality with uniform size ZnO NPs can be easily synthesized with reduced amount of time via solvothermal synthesis method rather than using other complicated and lengthy synthesis methods.
\end{abstract}

Keywords: Zinc Oxide nanoparticles; Solvothermal method; Small particle size; Spectroscopy

\section{Introduction}

High demands of nanomaterials have produced enormous applications in global industries. Due to high demand as NPs based products, various types of engineered nanoparticles (ENPs) are synthesized for myriad of applications. ${ }^{1}$ These days, ZnO NPs have become a promising candidates and gained more attention especially in nanomedicine and nano-semiconductors. ${ }^{2-4} \mathrm{ZnO}$ NPs exhibit wurtzite crystal structure that has been widely used in industries due to its unique optoelectric properties. ${ }^{5}$ $\mathrm{ZnO}$ NPs are among of various semiconductivity materials with a distinctive electronic and photonic wurtzite semiconductor with a wide direct band gap $(3.37 \mathrm{eV})$ and high exciton binding energy $(60 \mathrm{meV})$ at room temperature. ${ }^{6}$ This makes $\mathrm{ZnO}$ NPs particularly popular for use in commercially available especially in sunscreens and cosmetics which able to block UV radiation when they are less than $50 \mathrm{~nm}^{7-9}$ Heiligtag et al. ${ }^{10}$ stated that smaller size of NPs provide a better protection of skin against UV damage.
Besides, high optical absorption UVA and UVB in $\mathrm{ZnO}$ NPs are also beneficial in antimicrobial products in nanomedicine as nowadays various nanomaterials development have been applied to improve drugs and other medicine. ${ }^{11}$ Among other MO NPs, Salem et al. ${ }^{12}$ stated that $\mathrm{ZnO}$ NPs are the most recommended for antibacterial agent. Hence, the increase productions of consumer products eventually increase the productions of $\mathrm{ZnO}$ NPs. Heiligtag et al. ${ }^{10}$ has also stated that the potential applications of $\mathrm{ZnO}$ NPs make them one of a primary focus in NPs research. Naveed Ul Haq et al. ${ }^{13}$ also described that $\mathrm{ZnO}$ NPs is one of the cheap materials that this causes the extensive productions in industries. Morphologically, $\mathrm{ZnO}$ NPs is an attractive compound that possess thermal and chemical stability. ${ }^{14} \mathrm{ZnO}$ NPs are made into various shapes and sizes depending on the use of NPs in industries including textile, energy, food, cosmetics, and medicines and other characteristics that make them attractive for broad range of application. ${ }^{15}$ 
Various synthesis methods of $\mathrm{ZnO}$ NPs were developed into different size and forms in order to be used in commercial products. This includes sol-gel method, precipitation, microwave assisted, and thermal oxidation. ${ }^{4}$ However, these methods are considered complicated as they involve multiple steps procedures, lengthy reaction period, and toxic solvent and reactants might be used for synthesis. ${ }^{16,17}$ Prominent methods usually have undergone approximately 24 hours of reaction time to yield NPs products. For instance, Zarei et al. ${ }^{18}$ has synthesized $\mathrm{ZnO}$ NPs via sol-gel method in which more than 12 hours and high calcined temperature were required to produce $\mathrm{ZnO}$ NPs. Other than that, ZnO NPs synthesis via room-temperature method was also lengthy, as at least 4 days of synthesis was needed to prepare $\mathrm{ZnO} N \mathrm{NPs} .{ }^{19}$ Due to high cost and maintenance as well as lengthy preparation time to set up expensive equipment for synthesis, solvothermal synthesis was developed to synthesize NPs. Previous studies have carried out NPs synthesis via solvothermal method thus this study was carried out in order to support the method with some modifications mainly the use of absolute ethanol as a solvent.

According to Li et al., ${ }^{20}$ solvothermal process is defined as performing chemical reactions in solvents under specific temperature. Matei et al. ${ }^{21}$ also stated that solvothermal synthesis can be easily performed under controlled condition as $\mathrm{ZnO}$ NPs can be synthesized into different morphologies depending on the reaction conditions. Bai et al. ${ }^{22}$ has stated that solvothermal method has the ability in enhancing the dispersity of $\mathrm{ZnO}$ NPs. Besides, this process has been widely used specially to synthesize metal oxides NPs since it is more reliable, affordable, and undergo simpler process of synthesis. ${ }^{23} \mathrm{Wu}$ et al. ${ }^{17}$ also described that solvothermal synthesis method is free from using surfactant in which this offers a better potential for environmental friendly synthesis that can be produce in large quantities. Besides, solvothermal synthesis is considered one of the most promising approach to synthesize NPs. ${ }^{20}$ In solvothermal synthesis, organic solvent mainly alcohol such as ethanol as being used by previous researchers to synthesize $\mathrm{ZnO}$ NPs. ${ }^{4,23,24}$

Furthermore, NPs characterization using XRD, TEM, BET, EDX, FT-IR spectroscopy, and UV-Vis spectroscopy are fundamental steps especially for examining NPs surface properties and functionality. It is important to characterize NPs in order to determine the behaviour of NPs for further study such as toxicological studies. ${ }^{17}$ Due to extensive usage of $\mathrm{ZnO}$ NPs, $\mathrm{ZnO}$ NPs were prepared via solvothermal synthesis by using zinc acetate dihydrate $\left(\mathrm{Zn}\left(\mathrm{CH}_{3} \mathrm{COO}\right)_{2} \cdot 2 \mathrm{H}_{2} \mathrm{O}\right)$ as a zinc source and potassium hydroxide $(\mathrm{KOH})$ as a precursor which dissolved in organic solvent mainly ethanol as only short reaction period is required for the synthesis.

Ethanol was used for ZnO NPs synthesis as it has hydroxyl group that interact better with NPs as well as increase solubility to allow more interaction between parti- cles and capping molecules. ${ }^{25}$ This method has utilized the organic solvent mainly ethanol which generally has low boiling point and generate high pressure that are conducive to obtain a better product crystallization. ${ }^{26}$ The utilization of absolute ethanol as a solvent has proven to be monodisperse size and shape of $\mathrm{ZnO}$ NPs via solvothermal methods. Wang et al. ${ }^{26}$ has also explained that the presence of smaller surface tension of ethanol as compared to other alcohol has effectively contribute to inhibit the oxidation of powders thus uniform spherical $\mathrm{ZnO}$ NPs were formed. The aim of this research are to synthesize spherical $\mathrm{ZnO}$ NPs with less than $10 \mathrm{~nm}$ size by using zinc acetate dihydrate and potassium hydroxide with a absolute ethanol as solvent via solvothermal method and to characterize synthesized ZnO NPs using few techniques including XRD, TEM, BET, EDX, FT-IR, and UV-Vis spectroscopy.

\section{Experimental}

\section{1. Synthesis of Zinc Oxide Nanoparticles}

Zinc oxide nanoparticles was synthesized using solvothermal synthesis process from modified published procedures. ${ }^{24}$ Briefly, $1.48 \mathrm{~g}$ of $\mathrm{Zn}\left(\mathrm{CH}_{3} \mathrm{COO}\right)_{2} \cdot 2 \mathrm{H}_{2} \mathrm{O}$ (Sigma-Aldrich, India) was dissolved in $63 \mathrm{ml}$ of absolute ethanol (HmBG Chemicals) in a $250 \mathrm{ml}$ Schott bottle and was heated under $60^{\circ} \mathrm{C}$ with constant stirring. $0.74 \mathrm{~g}$ of $\mathrm{KOH}$ (VWR Amresco, US) was also dissolved separately in $33 \mathrm{ml}$ of absolute ethanol in $100 \mathrm{ml}$ Schott bottle under same condition of $\mathrm{Zn}\left(\mathrm{CH}_{3} \mathrm{COO}\right)_{2} \cdot 2 \mathrm{H}_{2} \mathrm{O}$. After both solutions have dissolved completely, dropwise, $\mathrm{KOH}$ was added into $\mathrm{Zn}\left(\mathrm{CH}_{3} \mathrm{COO}\right)_{2} \cdot 2 \mathrm{H}_{2} \mathrm{O}$ slowly under $60{ }^{\circ} \mathrm{C}$ with vigorous stirring. The mixture solution was left for 3 hours until the reaction was completed. A white precipitate $(\mathrm{ZnO})$ was formed and collected by centrifugation at 4000 rpm for 10 minutes, washed with acetone twice and ultrapure water once to remove all the impurities. The obtained product was then dried at room temperature and ground to form powder.

\section{2. Characterization of $\mathrm{ZnO}$ Nanoparticles}

Different techniques were used to characterize the synthesized ZnO NPs. Crystal structure and primary crystal size was characterized using XRD (Xpert Pro Diffractometer, Netherlands). The XRD pattern was obtained using X-ray diffractometer with $\mathrm{Cu}-\mathrm{Ka}$ radiation of $40 \mathrm{kV}$ and $30 \mathrm{~mA}$ with step size of $0.017^{\circ}$.

Other than that, the morphological features especially the size and the shape of ZnO NPs were determined using TEM (JOEL 1230, Japan). Basically, copper grid was prepared by applying fomvar coating on the copper grid. $\mathrm{ZnO}$ NPs were diluted with ethanol and sonicated with ultrasonic cleaner (Elma, Germany) for 30 minutes. Then, 4 $\mu \mathrm{l}$ of $\mathrm{ZnO}$ NPs sample was loaded onto the coated copper grid before being observed under TEM. 
Besides, Brunauer-Emmett-Teller (BET) (Quantachrome, US) was used to analyse the surface area of the synthesized $\mathrm{ZnO}$ NPs. About $0.3 \mathrm{~g}$ of $\mathrm{ZnO}$ NPs powder were placed in the tube and was allowed to degas at $175^{\circ} \mathrm{C}$ for 2 hours as referred to Zhou et al..$^{27}$ in flowing nitrogen. The $\mathrm{N}_{2}$ absorption-desorption isotherms of samples were then be measured. Energy-dispersive X-ray spectroscopy (EDX) was also being used for $\mathrm{ZnO}$ NPs characterization. EDX (JOEL 6390LA, Japan) was used in order to determine the purity of synthesized ZnO NPs. Meanwhile, Fourier transform infrared spectroscopy (FT-IR) was used in order to obtain the surface functional group that was present in $\mathrm{ZnO}$ NPs. ZnO NPs powder was mixed with potassium bromide $(\mathrm{KBr})$ with ratio of 1: 19. ${ }^{28}$ The sample was then placed in the metal hole, pressed until the sample compressed inside the hole, and analysed using FT-IR (Thermo scientific Nicolet iS10, US). Ultraviolet visible spectroscopy (UV-vis) (Perkin Elmer Lamda 25) was also used in order to determine the optical absorption spectra of $\mathrm{ZnO}$ NPs that was dispersed in water.

\section{Result and Discussion}

\section{1. X-Ray Diffraction (XRD)}

XRD pattern of synthesized $\mathrm{ZnO} N P$ is shown in Figure 1. Based on the XRD pattern, synthesized ZnO NPs has high purity of wurtzite crystalline structure as the diffraction peak is seen to be intense and narrower. This result was also being compared with the given standard XRD pattern of $\mathrm{ZnO}$ (JCPDS 36-1451) for confirmation purpose. The peak shown is broad which indicates that the particles is smaller which were also described in previous literature. ${ }^{22,26}$ Apart from that, as mentioned by Tagreed $e t$ al. ${ }^{29}$ the average crystalline structure (D) was calculated according to Debye-Scherrer's formula:

\section{Scherrer's Equation:}

Particle size $\left(D_{p}\right)=\frac{0.89 \lambda}{d \cos \theta}$

Where 0.89 refers to Scherrer's constant, is $\lambda$ a wavelength of X-rays, $\theta$ refers to Bragg diffraction angle, and $\mathrm{d}$ is full width at half maximum (FWHM) of diffraction peak. The most intense diffraction was chosen which is $<010>$ and the crystalline size of synthesized ZnO NPs was determined to be $10.08 \mathrm{~nm}$. Besides, the percentage of zinc content from the synthesized $\mathrm{ZnO}$ NPs via the XRD analysis, which revealed that there is $99 \%$ of zinc without any

Table 1. Pattern list of ZnO NPs obtained from XRD.

\begin{tabular}{cccc}
\hline $\begin{array}{c}\text { Chemical } \\
\text { formula }\end{array}$ & $\begin{array}{c}\text { Reference } \\
\text { code }\end{array}$ & $\begin{array}{c}\text { Compound } \\
\text { name }\end{array}$ & $\begin{array}{c}\text { Score } \\
\mathbf{( \% )}\end{array}$ \\
\hline $\mathrm{Zn}$ & $98-000-9346$ & Zincite & 99 \\
\hline
\end{tabular}

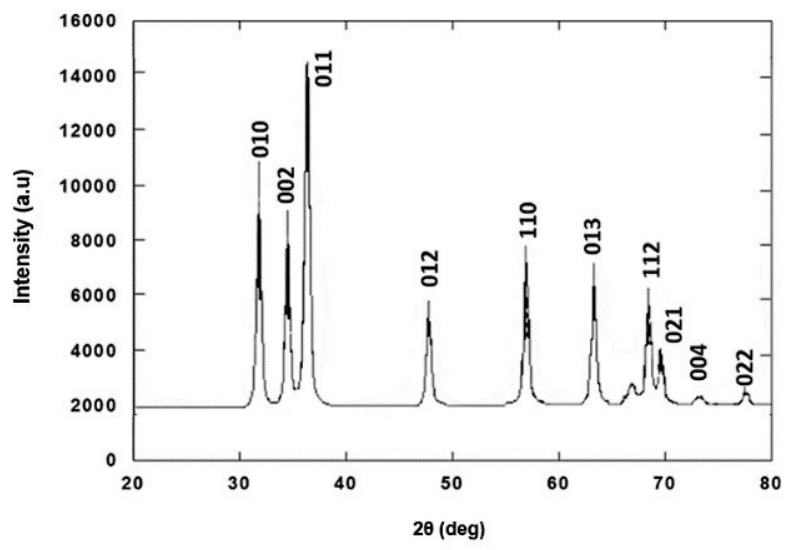

Figure 1. XRD pattern of synthesized $\mathrm{ZnO}$ nanoparticles.

other elements being detected as shown in Table 1. From this obtained data, it shows that synthesized $\mathrm{ZnO}$ NPs were determined to be of high purity.

\section{2. Transmission Electron Microscope (TEM)}

Physical characterization of NPs is commonly characterized using transmission electron microscope (TEM). Phoohinkong et al. ${ }^{30}$ stated that TEM was carried out in order to obtain high accuracy of the actual particle size and shape pattern. This shows that TEM is one of the reliable tools for NPs characterization. The morphological feature of synthesized $\mathrm{ZnO}$ NPs was determined using TEM as shown in Figure 2. Size of less than $10 \mathrm{~nm}$ was obtained by using solvothermal synthesis method. About 200 particles were chosen randomly and measured. The calculated mean size of synthesized ZnO NPs was determined to be $7.4 \pm 1.2 \mathrm{~nm}$. TEM particle distribution result in Figure 2 also confirmed that a narrow size distribution of $\mathrm{ZnO}$ NPs can be obtained via solvothermal synthesis

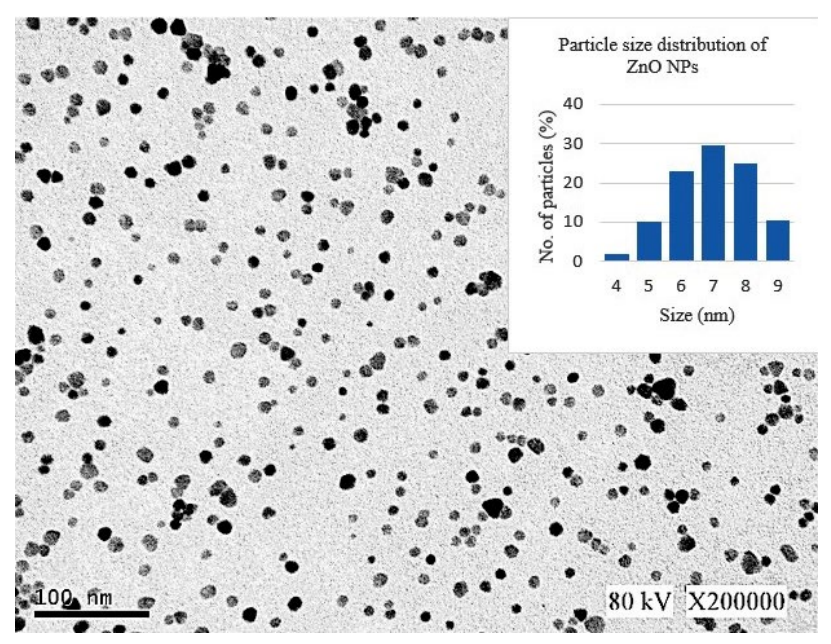

Figure 2. $\mathrm{ZnO}$ NPs image under transmission electron microscope (TEM) and particle size distribution of ZnO NPs. 
method. Based on the particle size distribution in the figure, most of the NPs measured were determined to be 6,7 , and $8 \mathrm{~nm}$ which attribute to $23 \%, 29.5 \%$ and $25 \%$, respectively. The biggest size of $\mathrm{ZnO}$ NPs measured is about $9 \mathrm{~nm}$ which only attribute to $10.5 \%$. Besides, synthesized $\mathrm{ZnO}$ NPs that was observed under TEM showed a homogenous shape that seem to be near hexagonal or nanosphere that was also described from previous study in which solvothermal synthesis was being conducted by Zak et al. ${ }^{23}$ which obtained $50 \mathrm{~nm} \mathrm{ZnO}$ NPs. The synthesized $\mathrm{ZnO}$ NPs observed under TEM also correlates with the XRD patterns that reveal high purity of wurtzite crystalline structure of $\mathrm{ZnO}$ NPs. Therefore, this shows that solvothermal synthesis can be used to obtain a better image that proves the presence of less than $10 \mathrm{~nm}$ of synthesized $\mathrm{ZnO}$ NPs with high dispersity.

\section{3. Brunauer-Emmett-Teller (BET)}

BET was carried out in order to determine the specific surface area for three different sized of $\mathrm{ZnO}$ NPs by $\mathrm{N}_{2}$ adsorption temperature of $77 \mathrm{~K}$. Figure 3 shows nitrogen $\left(\mathrm{N}_{2}\right)$ adsorption-desorption isotherms of $\mathrm{ZnO}$ NPs obtained from BET analysis (Quantachrome, US). Figure 3 also shows a typical type IV adsorption obtained from synthesized $\mathrm{ZnO}$ NPs. The isotherm relative was observed to be relative flat and similar result was also obtained by Zhou et al. ${ }^{27}$. Zhou et al. ${ }^{27}$ has described that the adsorption iso- therm was completely under superposition which usually occurs in micropores.

The specific surface area was also determined to be $101.32 \mathrm{~m}^{2} / \mathrm{g}$. Similar finding was also found from previous literature by Bian et al..$^{24}$ which obtained $105 \mathrm{~m}^{2} / \mathrm{g}$ for $4 \mathrm{~nm}$ $\mathrm{ZnO}$ NPs as measured by TEM. This shows that smaller NPs attribute to high surface area. Furthermore, the average particle can also be calculated from BET data. Since the shape of ZnO NPs was determined to be in spherical shape, average particle size can be calculated based on the equation $\mathrm{D}_{\mathrm{BET}}=6000 / \rho \cdot S_{\mathrm{w}}$ in which $\mathrm{D}_{\mathrm{BET}}$ is the average particle size, $\rho$ is the theoretical density of the sample which was $6.11 \mathrm{~g} \mathrm{~cm}^{-3}$, and $S_{\mathrm{w}}$ is the obtained surface area as referred to Zhou et al. ${ }^{27}$ and Ghasemzadeh et al. ${ }^{31}$. Table 2 summarised the BET results of $\mathrm{ZnO} N P$ s. The mean particle size of $\mathrm{ZnO}$ NPs obtained from BET $(9.7 \mathrm{~nm})$ is in agreement with the particle size obtained from TEM (7.4 $\mathrm{nm})$ and XRD (10.8 nm). Thus, this confirms that the particle size of synthesized $\mathrm{ZnO}$ NPs was in nanoscale which is approximately $10 \mathrm{~nm}$.

\section{4. Energy-dispersive X-ray Spectroscopy (EDX)}

The purity of $\mathrm{ZnO}$ NPs was determined via the EDX analysis. Figure 4 shows the EDX spectrum of $\mathrm{ZnO}$ NPs. EDX was used in order to determine the element composition that present in the samples. Result revealed that the

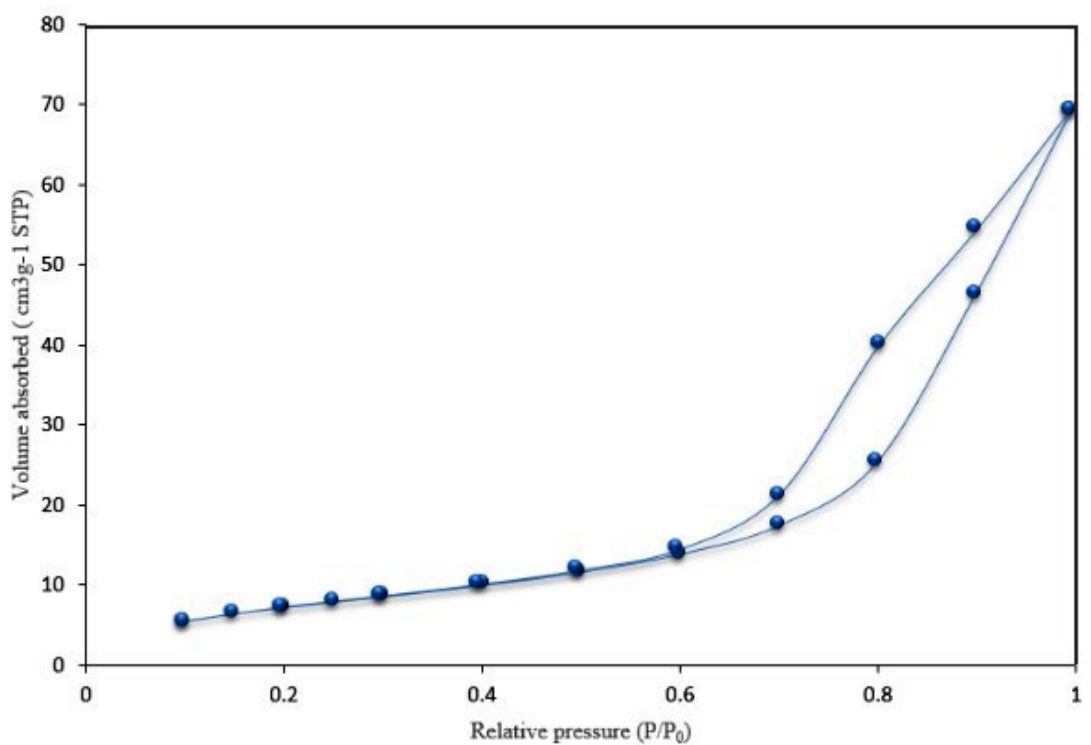

Figure 3. $\mathrm{N}_{2}$ adsorption- desorption isotherms of $\mathrm{ZnO} \mathrm{NPs}$

Table 2. BET results of synthesized $\mathrm{ZnO}$ NPs in comparison with other analytical techniques.

\begin{tabular}{ccccc}
\hline Constant/ C & $\begin{array}{c}\text { BET surface } \\
\text { area }\end{array}$ & $\begin{array}{c}\text { Average particle } \\
\text { size } \mathbf{D}_{\text {BET }}\end{array}$ & $\begin{array}{c}\text { Average size } \\
\text { via TEM }\end{array}$ & $\begin{array}{c}\text { Crystal size } \\
\text { via XRD }\end{array}$ \\
\hline 28.904 & $101.32 \mathrm{~m}^{2} / \mathrm{g}$ & $9.7 \mathrm{~nm}$ & $7.4 \mathrm{~nm}$ & $10.8 \mathrm{~nm}$ \\
\hline
\end{tabular}




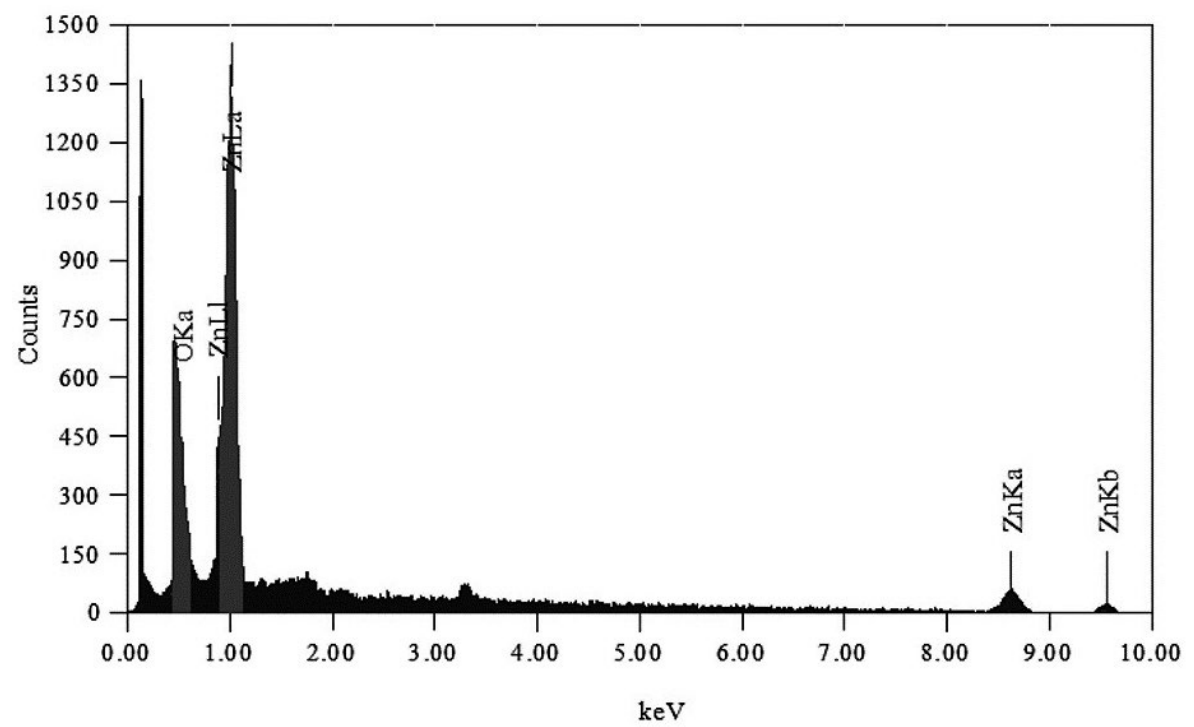

Figure 4. EDX pattern of $\mathrm{ZnO}$ NPs

EDX data was composed of two elements which are $\mathrm{Zn}$ (76.3\%) and $\mathrm{O}(23.7 \%)$. This result has confirmed that the $\mathrm{ZnO}$ NPs has high purity. Similar finding was also found in previous studies by Brintha and Ajitha ${ }^{32}$ that obtained the mass percentage of $\mathrm{Zn}$ and $\mathrm{O}$ were $73.9 \%$ and $26.1 \%$, respectively. Hasnidawi et al. ${ }^{33}$ has stated that the theoretical expected mass percent of $\mathrm{Zn}$ and $\mathrm{O}$ were $80.3 \%$ and $19.7 \%$. Thus, the EDX result revealed that the synthesized $\mathrm{ZnO}$ NPs were of high purity, which contain high $\mathrm{Zn}$ and O element composition.

\section{5. Fourier Transform Infrared Spectroscopy (FT-IR)}

FT-IR was performed in order to study and determine the functional groups of synthesized $\mathrm{ZnO}$ NPs. Fig- ure 5 showed the FT-IR spectrum of synthesized $\mathrm{ZnO}$ NPs that were obtained from solvothermal synthesis procedure. FT-IR spectrum analysis was done by referring to Yang et al..$^{28}$ where a broad absorption band was observed at $414 \mathrm{~cm}^{-1}$ that attribute to $\mathrm{Zn}-\mathrm{O}$ stretching vibration. In previous studies regarding $\mathrm{ZnO}$ NPs they were also able to observe FT-IR spectrum with the band around 400 $\mathrm{cm}^{-1}$. $23,28,34$

All the observed peaks were referred from previous literatures in order to confirm the findings. Similar findings were also found from previous studies related to $\mathrm{ZnO}$ NPs synthesis and characterization. The peaks at 1339 and $1556 \mathrm{~cm}^{-1}$ were symmetric and asymmetric O-C-O stretching vibration of adsorbed carbonate anion respectively. Meanwhile, the peaks at $1047 \mathrm{~cm}^{-1}$ that indicate the lattice vibration of carbonate generated absorption peaks.

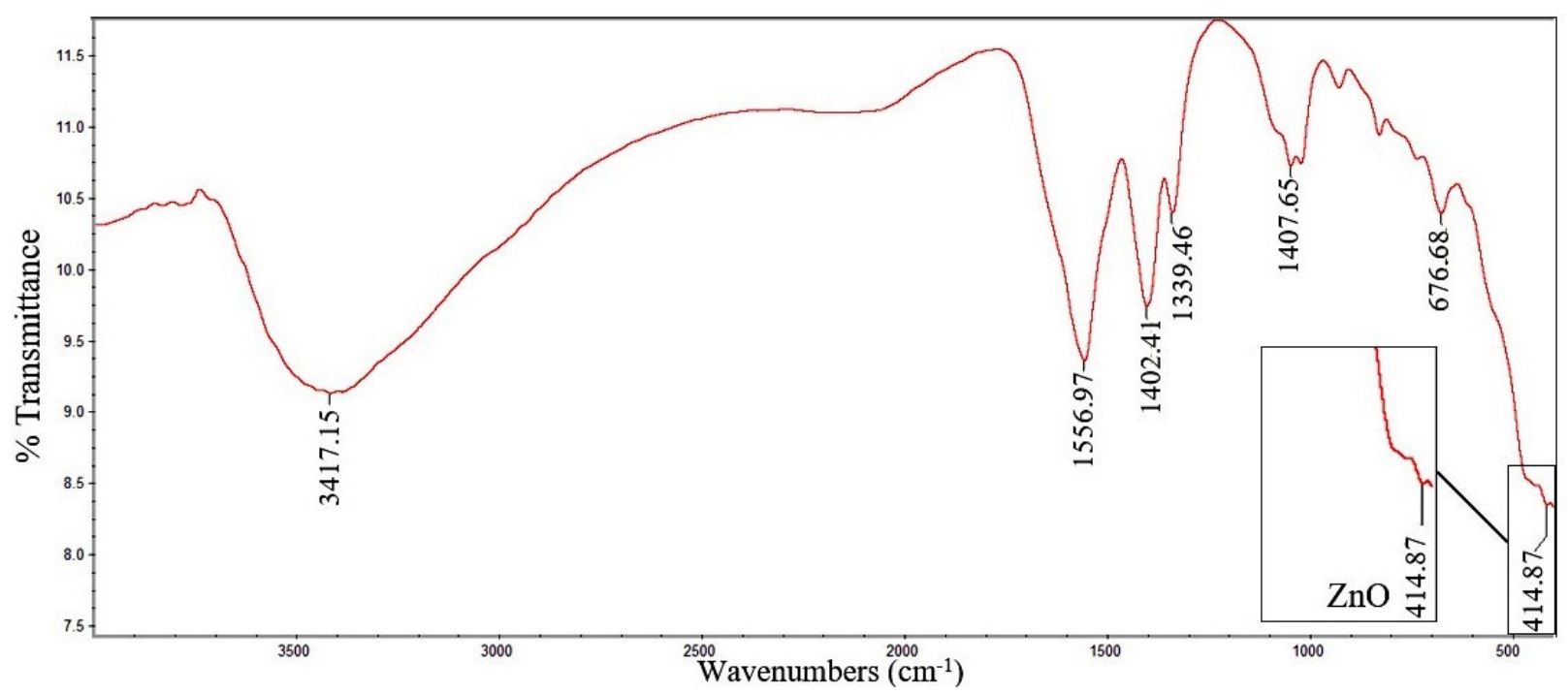

Figure 5. FT-IR spectrum of synthesized ZnO NPs. 
Besides, hydroxyl group stretching can be seen at the absorption peak of $3417 \mathrm{~cm}^{-1}$.

Apart from that, peaks of $1402 \mathrm{~cm}^{-1}$ and $1339 \mathrm{~cm}^{-1}$ indicate the presence of $\mathrm{Zn}\left(\mathrm{CH}_{3} \mathrm{COO}\right)_{2} \cdot 2 \mathrm{H}_{2} \mathrm{O}$ that associate with $\mathrm{CH}_{3}$ bending modes similar with result obtained by previous literature. ${ }^{17}$ Many $\mathrm{ZnO}$ NPs has been made using different types of synthesis method, however the obtained FT-IR spectrum regarding ZnO NPs synthesis have shown similarities..$^{35,36}$ Therefore, FT-IR result has shown to be high purity of synthesized $\mathrm{ZnO} \mathrm{NPs}$. Wu et al. ${ }^{17}$ has stated that this technique provides information about surface functional group that are present on surface that give a useful description of surface speciation.

\section{6. UV-Vis Absorption Spectrum}

UV-Vis spectroscopy was also performed to further confirm the formation of $\mathrm{ZnO}$ NPs. The absorption spectrum of synthesized $\mathrm{ZnO}$ NPs was shown in Figure 6. The UV-Vis measurement was performed after the ZnO NPs was dispersed in ultrapure water. The absorption peak was observed at $357 \mathrm{~nm}$, which attribute to the intrinsic band-gap of $\mathrm{Zn}-\mathrm{O}$ absorption. Similar result of absorption band that represent $\mathrm{ZnO}$ NPs was also obtained from previous research in which the range of ab-

Table 3. UV vis absorption peak of $\mathrm{ZnO}$ from previous literatures.

\begin{tabular}{cc}
\hline Author & UV absorption peak $(\mathbf{n m})$ \\
\hline Talam et al. ${ }^{4}$ & 355 \\
Zak et al. & 370 \\
Bian et al. & .4 \\
Lavand et al. & 371 \\
Akhil et al. ${ }^{37}$ & 375 \\
\hline
\end{tabular}

sorption band were from 355 to $380 \mathrm{~nm}$ as summarised in Table 3. ${ }^{4,23,24,34,37}$ These supporting data confirm the presence of $\mathrm{ZnO}$ NPs as the absorption band obtained are similar. Wang et al. ${ }^{26}$ also obtained similar findings which deduced that the obtained peak showed a better UV absorption for ZnO NPs.

Furthermore, the absorption peak of $\mathrm{ZnO}$ NPs also confirmed the properties of $\mathrm{ZnO}$ NPs, which is known for UV protections in sunscreens products. ${ }^{38}$

\section{5. Absolute Ethanol as a Solvent}

From the obtained TEM result as shown in Figure 2, it shows that solvent also plays an important role for $\mathrm{ZnO}$ NPs synthesis. This includes the physico-chemical properties of $\mathrm{ZnO}$ NPs in terms of size and shape. The utilization of absolute ethanol as a solvent has formed a highly dispersed small ZnO NPs with uniform shape and size that was determined to be less than $10 \mathrm{~nm}$ as expected. Similar finding also described the formation of spherical shape of $\mathrm{ZnO}$ when ethanol was being used as a solvent. ${ }^{14}$ This study has shown that the absolute ethanol is one of the suitable solvent to be used to synthesize $\mathrm{ZnO}$ NPs via solvothermal synthesis method. Wang et al. ${ }^{26}$ has found that different alcohol gives significant effect on $\mathrm{ZnO}$ NPs in terms of their morphology. Previous studies have also used other alcohol for ZnO NPs synthesis however, different forms of $\mathrm{ZnO}$ NPs were produced such as rod, flower-shaped, tubes, and etc. ${ }^{22}$ Therefore, eminent production of $\mathrm{ZnO}$ NPs with uniform spherical shape with high dispersity can be easily obtained by utilizing ethanol as a solvent for solvothermal synthesis method. Other benefit of using absolute ethanol would be the short period of synthesis process needed to produce less than $10 \mathrm{~nm}$ of $\mathrm{ZnO}$ NPs with uniform size.

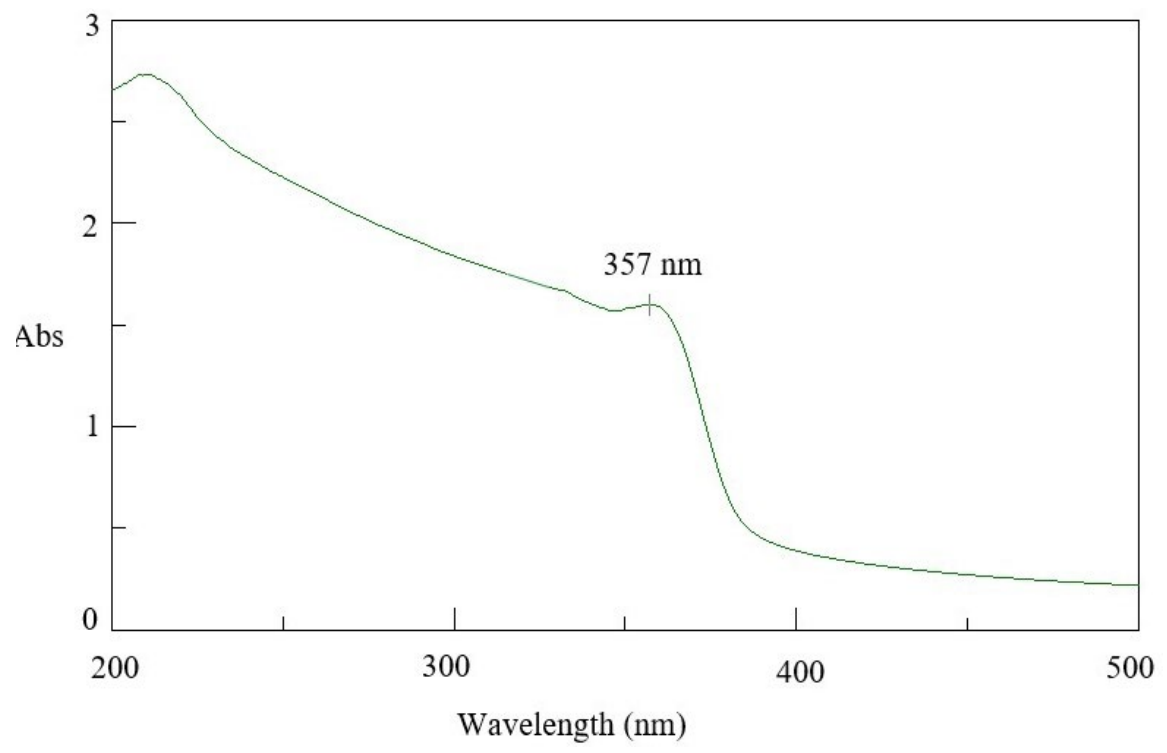

Figure 6. UV-Vis absorption spectra of synthesized ZnO NPs. 


\section{Conclusion}

$\mathrm{ZnO}$ NPs with less than $10 \mathrm{~nm}(7.4 \mathrm{~nm})$ was successfully prepared by using zinc acetate dihydrate and potassium hydroxide via the solvothermal synthesis process. The utilization of absolute ethanol as a solvent was able to produce uniform shape and better dispersity of $\mathrm{ZnO}$ NPs. Synthesized ZnO NPs were also able to be confirmed by various characterization techniques including XRD, TEM, FT-IR, and UV-vis spectroscopy. XRD has revealed a wurtzite crystalline structure of ZnO NPs where by physical characterization of $\mathrm{ZnO}$ NPs was determined by using TEM and size less than $10 \mathrm{~nm}$ of $\mathrm{ZnO} N$ Ps was obtained. BET revealed that the synthesized $\mathrm{ZnO}$ NPs has high surface area that correlate with the particle size obtained from TEM. EDX has proven the purity of synthesized ZnO NPs which contain high $\mathrm{Zn}$ and $\mathrm{O}$ element composition. FT-IR and UV-vis spectroscopy also showed the absorbance spectrum that indicates the presence of $\mathrm{ZnO}$ NPs. Therefore, solvothermal synthesis method is one of the most suitable methods to obtain a better quality of $\mathrm{ZnO}$ NPs. This study also presents a potential effective method to prepare $\mathrm{ZnO}$ NPs within shorter time with smaller particle size distribution.

\section{Acknowledgement}

Authors sincerely thank MOHE grant FRGS/ ST01(01)/1208/2014(09) for the funding, Faculty of Resource Science and Technology (FRST) for providing the necessary facilities to carry out this research. Authors also want to thank Mdm Ting Woei for the TEM image results.

\section{References}

1. M. A. Maurer-Jones, I. L. Gunsolus, C. J. Murphy, C. L. Haynes, Anal. Chem., 2013, 85, 3036-3049.

DOI: $10.1021 / \mathrm{ac} 303636 \mathrm{~s}$

2. B. Liu \& H. C. Zeng, J. Am. Chem. Soc., 2003 125, 4430-4431. DOI: $10.1021 / \mathrm{ja} 0299452$

3. V. Sharma, R. K. Shukla, N. Saxena, Toxicol. Lett., 2009, 185, 211-218. DOI 10.1016/j.toxlet.2009.01.008

4. S. Talam, S. R. Karumuri, \& N. Gunnam, ISRN Nano, 2012, 1-6. DOI: $10.5402 / 2012 / 372505$

5. H. Ma, P. L. Williams, S. A. Diamond. Environ. Pollut., 2013, 172, 76-85. DOI: 10.1016/j.envpol.2012.08.011.

6. A. Kołodziejczak-Radzimska, T. Jesionowski, Mater, 2014, 7, 2833-2881. DOI:10.3390/ma7042833

7. L. K. Adams, D. Y. Lyon, P. J. Alvarez, Water Res., 2006, 40, 3527-3532. DOI: 10.1016/j.watres.2006.08.004

8. I. Blinova, A. Ivask, M. Heinlaan, M. Mortimer, A. Kahru, Environ. Pollut., 2010, 158, 41-47.

DOI: $10.1016 /$ j.envpol.2009.08.017

9. L. C. Wehmas, C. Anders, J. Chess, A. Punnoose, C. B. Pereira,
J. A. Greenwood, R. L. Tanguay, Toxicol Rep, 2015, 2, 702-

715. DOI:10.1016/j.toxrep.2015.03.015

10. F. J. Heiligtag \& M. Niederberger, Mater. Today, 2013, 16, 262-271. DOI: 10.1016/j.mattod.2013.07.004

11. S. Gunalan, R. Sivaraj, V. Rajendran, Mater Int., 2012, 22, 693-700. DOI: 10.1016/j.pnsc.2012.11.015

12. W. Salem, D. R. Leitner, F. G. Zingl, G. Schratter, R. Prassl, W. Goessler, S. Schild, Int J Med Microbiol, 2015, 305, 85-95. DOI: $10.1016 /$ j.ijmm.2014.11.005

13. A. Naveed Ul Haq, A. Nadhman, I. Ullah, G. Mustafa, M. Yasinzai, \& I. Khan. J. Nanomater., 2017. DOI: $10.1155 / 2017 / 8510342$

14. A. Šarić, G. Štefanić, G. Dražić, \& M. Gotić, J. Alloys Compd, 2015, 652, 91-99.

DOI: $10.1016 /$ j.jallcom.2015.08.200

15. E. Hughes, Big problems with little particles? Chemistry World, http://www.rsc.org/chemistryworld/2015/04/nanoparticle-toxicology (assessed: September 16, 2017)

16. K. D. Bhatte, D. N. Sawant, R. A. Watile, B. M. Bhanage, Mater. Lett., 2012, 69, 66-68. DOI: 10.1016/j.matlet.2011.10.112

17. C. M. Wu, J. Baltrusaitis, E. G. Gillan, V. H. Grassian, J. Phys. Chem. C, 2011, 115,10164-10172. DOI: 10.1021/jp201986j

18. N. Zarei, \& M. A. Behnajady, J. Ind. Eng. Chem. Res., 2016, 57(36), 16855-16861. DOI: 10.1080/19443994.2015.1083479

19. A. Bagabas, A. Alshammari, M. F. Aboud, \& H. Kosslick, Nanoscale Res Lett., 2013, 8(1), 516.

DOI: $10.1186 / 1556-276 \mathrm{X}-8-516$

20. J. Li, Q. Wu, J. Wu, Handb. Nano., 2016, 295-328. DOI: 10.1007/978-3-319-15338-4_17

21. A. Matei, V. Tucureanu, L. Dumitrescu, Bull. Transilv. Univ. Brasov Ser. I, 2014, 7, 45.

22. X. Bai, L. Li, H. Liu, L. Tan, T. Liu, \& X. Meng, ACS Appl. Mater. Interface, 2015, 7, 1308-1317. DOI: 10.1021/am507532p

23. A. K. Zak, R. Razali, W. H. Majid, M. Darroudi, Int. J. Nanomedicine., 2011, 6, 1399-1403. DOI: 10.2147/IJN.S19693.

24. S. W. Bian, I. A. Mudunkotuwa, T. Rupasinghe, V. H. Grassian, Langmuir, 2011, 27, 6059-6068. DOI: 10.1021/la200570n

25. P. B. Khoza, M. J. Moloto, L. M. Sikhwivhilu. J. Nanotechnol., 2012, 1-7. DOI: 10.1155/2012/195106

26. Y. X. Wang, J. Sun, \& X. Yu, In Mater. Sci. Forum, 2011, 663, 1103-1106. DOI:10.4028/www.scientific.net/MSF.663-665.1103

27. M. Zhou, Z. Wei, Qiao, H., L. Zhu, H. Yang, \& T. Xia. Particle size and pore structure characterization of silver nanoparticles prepared by confined arc plasma. J. Nanomater, 2009, 3.

28. K. Yang, D. Lin, B. Xing, Langmuir, 2009, 25, 3571-3576. DOI: $10.1021 /$ la803701b.

29. M. A. Tagreed, A. B. Nabeel, A. H. Noor, Int. J. Eng. Tech. Res., 2014, 2, 191-195.

30. W. Phoohinkong, T. Foophow, \& W. Pecharapa, Adv. Nat. Sci., 2017, 8, 035003.

31. M. A. Ghasemzadeh, \& J. Safaei-Ghomi, Cogent Chem., 2015 1(1), 1095060. DOI: 10.1080/23312009.2015.1095060

32. S. R. Brintha, \& M. Ajitha, Synthesis and characterization of $\mathrm{ZnO}$ nanoparticles via aqueous solution, sol-gel and hydrothermal methods. IOSR J. Appl. Chem, 2015 8(11), 66-72. 
33. J. N. Hasnidawani, H. N. Azlina, H. Norita, N. N. Bonnia, S. Ratim, \& E. S. Ali, Synthesis of $\mathrm{ZnO}$ nanostructures using solgel method. Pro Chem, 2016, 19, 211-216.

34. A. B. Lavand, Y. S. Malghe. Int. J. Photochem., 2015, 305-310. DOI: $10.1016 /$ j.jksus.2016.08.009

35. M. A. Mustafa, D. A. M. Osman. J. Nanosci. Nanoeng., 2016, $1,248-251$.
36. C. Jayaseelan, A. A. Rahuman, A. V. Kirthi, S. Marimuthu, T. Santhoshkumar, A. Bagavan, K. B. Rao. Spectrochim Acta A, 2012, 90, 78-84. DOI: 10.1016/j.saa.2012.01.006.

37. K. Akhil, S. S. Khan, J. Photochem. Photobio. B, 2017, 167, 136-149. DOI: 10.1016/j.jphotobiol.2016.12.010.

38. M. M. N. Yung, C. Mouneyrac, K. M. Y. Leung, Encyclop. Nano., 2014, 1-17.

DOI: 10.1007/978-94-007-6178-0_100970-1

\section{Povzetek}

Solvotermalna sinteza ima velik potencial za pripravo nanodelcev cinkovega oksida $(\mathrm{ZnO})$ manjših od $10 \mathrm{~nm}$. V tej študiji predstavljamo razmeroma hitro in enostavno sintezo nanodelcev $\mathrm{ZnO}$ pri kateri imajo sintetizirani nanodelci $\mathrm{ZnO}$ bolj enakomerno obliko in so visoko dispergirani. Za sintezo smo uporabili cinkov acetat dihidrat $\left(\mathrm{Zn}\left(\mathrm{CH}_{3} \mathrm{COO}\right)_{2}\right.$ $\left.\cdot 2 \mathrm{H}_{2} \mathrm{O}\right)$ in kalijev hidroksid $(\mathrm{KOH})$ ter absolutni etanol kot topilo. Tako sintetizirane nanodelce $\mathrm{ZnO}$ smo karakterizirali z naslednjimi metodami: rentgensko praškovno difrakcijo (XRD), presevno elektronsko mikroskopijo (TEM), Brunauer-Emmett-Tellerjem metodo merjenja specifične površine (BET), energijsko disperzivno rentgensko spektroskopijo (EDX), infrardečo spektroskopijo (FT-IR) in UV-Vis spektroskopijo. Nanodelce ZnO s strukturo wurtzita, kristalinično velikostjo $10,08 \mathrm{~nm}$ in velikostjo delcev $7,4 \pm 1,2 \mathrm{~nm}$ smo pripravili s solvotermalne sintezno metodo pri $60^{\circ} \mathrm{C} \mathrm{v}$ treh urah. UV-Vis absorpcijski spekter je pokazal vrh pri $357 \mathrm{~nm}$, kar kaže na prisotnost nanodelcev ZnO. S predlagano solvotermalno metodo lahko pripravimo nanodelce $\mathrm{ZnO}$, ki so enake velikosti in hkrati skrajšamo čas priprave. 